\title{
Ascending upper limb lymphangitis
}

\author{
Leopold Simma, ${ }^{1,2}$ Michael Joseph Barrett ${ }^{1,3}$
}

'Emergency Department, Royal Children's Hospital Melbourne, Parkville, Victoria, Australia ${ }^{2}$ Emergency Department, Children's Hospital, Luzerner Kantonsspital, Lucerne, Switzerland

${ }^{3}$ Emergency Department, Our Lady's Children's Hospital, Dublin, Ireland

\section{Correspondence to}

Dr Leopold Simma,

leopold.simma@luks.ch

Accepted 15 September 2017
CrossMark

To cite: Simma L, Barrett MJ. BMJ Case Rep Published Online First: [please include Day Month Year]. doi:10.1136/bcr-2017221602

\section{DESCRIPTION}

A 7-year-old boy presented with ascending erythema of his left hand with erythematous extension to his axilla. At presentation, the boy was afebrile, well appearing and complained of itching and swelling of the hand, which started the evening prior. On examination, there were two insect bite marks on the index finger with erythematous, non-tender swelling inclusive of the index, middle fingers and dorsum of

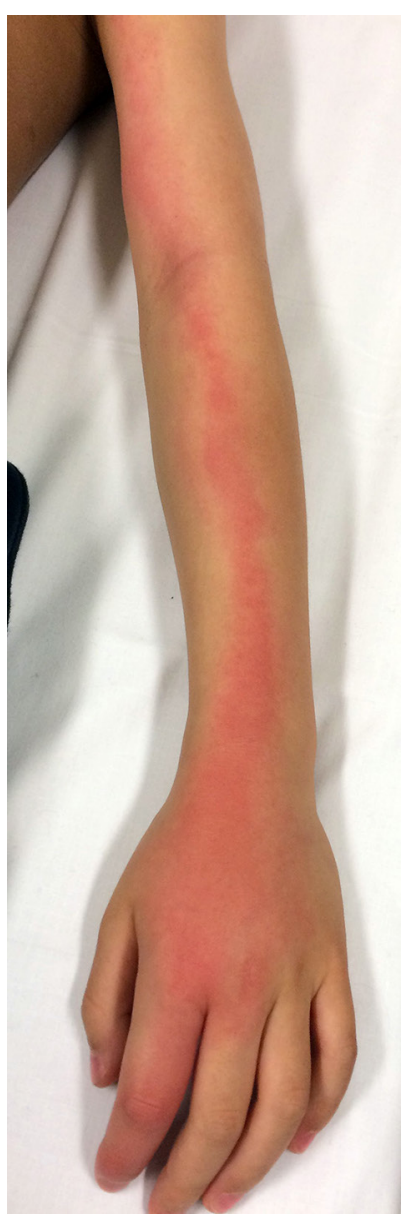

Figure 1 At the bedside: oedematous left index finger with two insect bites. Erythema tracking proximally.
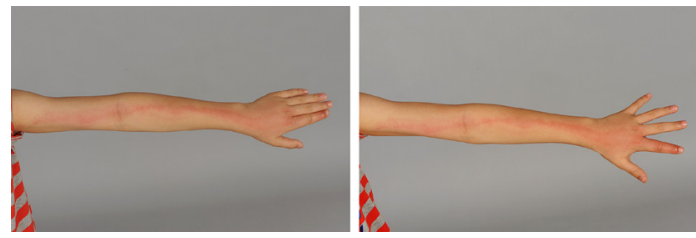

Figure 2 Ascending track of erythema originating from the index finger affecting the lymphatic system of the upper limb.

the hand with extension via a superficial fine erythematous line from the wrist to the axilla via the cubital fossa figures 1 and 2). A clinical diagnosis of lymphangitis was made. Treatment was commenced with flucloxacillin and immobilisation. Twenty-four hours later, the erythema had faded substantially. Lymphangitis is inflammation of the lymphatic channels that occur as a result of infection at a site distal to the channel and may spread within hours. Group A beta-haemolytic streptococci are the most common causes of bacterial lymphangitis and, in severe cases, can lead to bacteraemia, sepsis and death. ${ }^{1}$ He had no complication or reoccurrence.

\section{Learning points}

- Minor lesions can result in impressive cutaneous findings.

- Do not forget to immobilise the affected limb.

Contributors LS was the treating physician, obtained photos and parent consent and drafted the vignette. MJB contributed significantly to the manuscript.

Competing interests None declared.

Patient consent Guardian consent obtained.

Provenance and peer review Not commissioned; externally peer reviewed.

(C) BMJ Publishing Group Ltd (unless otherwise stated in the text of the article) 2017. All rights reserved. No commercial use is permitted unless otherwise expressly granted.

\section{REFERENCE}

1 Yamamoto LG. Treatment of skin and soft tissue infections. Pediatr Emerg Care 2017;33:49-55. Review. 
Copyright 2017 BMJ Publishing Group. All rights reserved. For permission to reuse any of this content visit http://group.bmj.com/group/rights-licensing/permissions.

BMJ Case Report Fellows may re-use this article for personal use and teaching without any further permission.

Become a Fellow of BMJ Case Reports today and you can:

- Submit as many cases as you like

- Enjoy fast sympathetic peer review and rapid publication of accepted articles

Access all the published articles

- Re-use any of the published material for personal use and teaching without further permission

For information on Institutional Fellowships contact consortiasales@bmjgroup.com

Visit casereports.bmj.com for more articles like this and to become a Fellow 